Regular Article

pISSN: 2287-2396, eISSN: 2287-240X

Journal of Forest Science

Vol. 30, No. 1, pp. 15-29, February, 2014

http://dx.doi.org/10.7747/JFS.2014.30.1.15

\title{
Present State of Community Forestry (Hutan Kemasyarakatan/HKm) Program in a Protection Forest and Its Challenges: Case Study in Lampung Province, Indonesia
}

\author{
Hari Kaskoyo ${ }^{1,2, *}$, Abrar Juhar Mohammed ${ }^{1}$ and Makoto Inoue ${ }^{1}$ \\ ${ }^{1}$ Department of Global Agricultural Sciences, Graduate School of Agricultural and Life Sciences, The University of Tokyo, Tokyo 113-8657, Japan \\ ${ }^{2}$ Department of Forestry, Faculty of Agriculture, University of Lampung, Bandar Lampung, 35145, Indonesia
}

\begin{abstract}
This article discusses the state of a community forestry program in a protection forest in Indonesia, which has been running for almost two decades. We found that the program did not achieve its objective mainly because of frequent changes in regulations. There are also activities such as: measuring and mapping working area boundaries, drawing up a work plan, planting, maintenance and security, paying royalties to those who harvest forest resources, and submitting annual reports on land use to the district government head, which have not worked as expected. We also found that the major incentives for local people to participate in the program are getting certificates of management and the program's effectiveness in minimizing land-use conflicts. Participants perceived that their major role on the program is to follow farmer-group directives or government rules. To achieve the program's purposes, farmer groups need technical assistance related to protection-forest management and opportunities for financing.
\end{abstract}

Key Words: community forestry, hutan kemasyarakatan, protection forest, forest management

\section{Introduction}

The more than two decades of community forestry $(\mathrm{CF})$ in Indonesia started by involving communities in forest management in collaboration with forestry companies (Fay and de Foresta 1998; Colchester 2001). CF is closely connected to poverty alleviation, empowerment of forest users, and improvement of forest conditions (Maryudi et al. 2012). Such CF scheme is implemented in all the three types of state forests, i.e. conservation forests (Hutan Konservasi), production forests (Hutan Produksi), and pro- tection forests (Hutan Lindung). Of these, CF in protection forest has been the least researched but the most interesting because of the vitality of the environmental and livelihood objective it has to achieve.

Protection forests are those which have a strategic value because in addition to protecting life-support systems, they are a source of livelihood for the nearby communities. These forests are managed by provincial and district governments. One of the province in which the protection forest is the most extensive forest managed by local governments is Lampung. Under the Ministry of Forestry Act

Received: February 15, 2013. Revised: September 20, 2013. Accepted: September 23, 2013

Corresponding author: Hari Kaskoyo

Department of Global Agricultural Sciences, Graduate School of Global Agriculture and Life Sciences, The University of Tokyo, 1-1-1 Yayoi, Bunkyo-ku, Tokyo 113-8657, Japan

Tel: 81-3-5841-7508, Fax: 81-3-5841-7509, E-mail: harikaskoyo@gmail.com 
Table 1. Forest condition in Lampung Province

\begin{tabular}{|c|c|c|c|c|c|c|c|c|}
\hline \multirow{3}{*}{ Forest function } & \multicolumn{6}{|c|}{ Forest cover category } & \multirow{2}{*}{\multicolumn{2}{|c|}{ Total }} \\
\hline & \multicolumn{2}{|c|}{ Covered } & \multicolumn{2}{|c|}{ Non covered } & \multicolumn{2}{|c|}{ No data } & & \\
\hline & $(\mathrm{Ha})$ & $(\%)$ & (Ha) & $(\%)$ & $(\mathrm{Ha})$ & $(\%)$ & $(\mathrm{Ha})$ & $(\%)$ \\
\hline Conservation Forest & 140.700 & 32.68 & 193.244 & 44.89 & 96.530 & 22.42 & 430.474 & 100 \\
\hline Protection Forest & 44.400 & 13.98 & 260.600 & 82.05 & 12.615 & 3.97 & 317.615 & 100 \\
\hline Limited Production Forest (HPT) & 5.000 & 14.99 & 26.558 & 79.62 & 1.800 & 5.40 & 33.358 & 100 \\
\hline Fixed Production Forest & 8.200 & 4.28 & 161.600 & 84.28 & 21.932 & 11.44 & 191.732 & 100 \\
\hline Totals & 198.300 & 20.38 & 642.002 & 65.97 & 132.877 & 13.65 & 973.179 & 100 \\
\hline
\end{tabular}

Source : Lampung Province Forestry Office, 2008.

No.256/Kpts-II/2000, the protection forest in Lampung covers 317.615 ha $(31.61 \%$ of total forest area in Lampung) and is divided into 27 registers (Lampung Provincial Forestry Office 2008). Despite such function of the protection forest, large portion $(82 \%)$ of the area designated as protection has been deforested (Table 1).

One of the measures taken to alleviate such deforestation is community forest (Hutan Kemasyarakatan/HKm). $\mathrm{HKm}$ is a CF program established by Indonesia's government with the objective of empowering local communities by granting them the rights to use protection-forest land (Arifin 2006) and to practice sustainable forest management, thereby sustaining forest functions and the environment, and improving social well-being (Pender et al. 2008). Although this program is being implemented in this salient landscape, i.e. protection forest, there has been scarcity of literature that explored the process of its implementation, its current status as well as challenges faced by the program. This paper aims to fill the aforementioned research gap by addressing the following three objectives. The first is to investigate the implementation process of $\mathrm{HKm}$. Secondly we assesses the current socioeconomic state of the HKm participants and vegetation condition of the HKm site. Finally, we investigate the challenge faced for implementation of $\mathrm{HKm}$.

The remaining part of the paper is organized as follows. The next section, theoretical framework, discusses what CF mean and important aspects that should be assessed to explore CF programs. The research methods section elaborates the study site, data collection and analysis methods. The important outcomes of the research are detailed and discussed in the Result and discussion section. The last section is the conclusion and policy implication section.

\section{Theoretical Framework}

Community forestry (CF) is known by different names in many region such as South Asia, Southeast Asia, and Africa. For example, it is Joint Forest Management (JFM) in India, Community Based Forest Management (CBFM) in the Philippines, Community Forestry in Nepal, village Forestry in Laos (Balooni and Inoue 2007; Pulhin and Inoue 2008) and Participatory Forest Management in Ethiopia (Mohammed and Inoue 2012a). In Indonesian too, there are different forms of community forestry which include collaborative forest management (Kemitraan), community forest (Hutan Kemasyarakatan/HKm), village forest (Hutan Desa/HD), community plantations forest (Hutan Tanaman Rakyat/HTR), and customary forest (Hutan Adat). All these, in fact, have varying connotations because there are different degrees and levels of people's participation in forest management and the decision-making process in these countries as well as within the country depending on the state's willingness to move away from the command and control approach (Balooni and Inoue 2007).

The different forms of $\mathrm{CF}$ in Indonesia also have distinctive character and legal basis. HKm is the state's forest, managed by people's group, mainly utilized for the empowerment of the local people as well as to practice sustainable forest management on production forest and protection forest lands (Arifin 2006; Pender et al. 2008; Nanang and Inoue 2000). The legal basis of $\mathrm{HKm}$ is the Minister of 
Forestry Regulation Number P.37/Menhut-II/2007 in conjunction with Number P.52/Menhut-II/2011. Kemitraan is formally recognize local people and civil society organizations such as NGOs can be formal partners in conservation forest management based on Minister of Forestry Regulation Number P.19/Menhut-II/2004 (Kubo 2008; Kubo and Supriyanto 2010). Village Forest (HD) is the national forest estate managed by formal village organization that plans, manages and allocates benefits derived from the production and protection forests. The management is not exclusively focused on utilization of forest resources, but includes responsibilities to preserve the life-supporting functions of the forest (Akiefnawati et al. 2010). The Legal Basis for HD is Minister of Forestry Regulation Number P.49/Menhut-II/2008 in conjunction with Number P.53/ Menhut-II/2011. Community plantation forest (HTR) is a timber plantation established in degraded production forest areas by individuals, households, or village cooperatives to improve the productivity potential of the forest through enrichment planting and the application of appropriate silvicultural practices as well as to support timber plantation development in the state production forest, whereas other community forestry schemes are located largely outside of the state forest (Obidzinski and Dermawan 2010). HTR's license is in accordance to the Minister of Forestry Regulation Number P.55/Menhut-II/2011 concerning Procedure of Requesting IUPHHK-HTR within the Plantation Forest. Hutan Adat is forest inside the state forest which community practices customary law (Nanang and Inoue 2000). The legal basis of hutan adat is basic forestry law no 41/1999.

Community forestry in general, $\mathrm{HKm}$ in particular, is mainly implemented to address two objectives, i.e. improving livelihood of local people and forest condition (Larson and Soto 2008; Mohammed and Inoue 2012b). Therefore, two important factors that need consideration in assessing such program is the livelihood issues and forest conditions. The overall success of $\mathrm{CF}$ is also dependent on local people participation as the major stakeholders in such program are local people. In fact, at the center of the interest in the transition from centralized forest policy to CBNRM is the involvement of local people in decision makings (Feeny et al. 1990). Among the important factors that affects participation of local people is institutional and economic factors
(Hlaing and Inoue 2013). Economic factors that particularly important for local people is income they get from the program. Ostrom (2007) also pointed out that if users do not feel that they obtain a major part of their income from a resource, they may not be willing to execute the collective responsibilities.

Institutions are rules at work (Ostrom 1990). They shape interaction of local people involved in $\mathrm{CF}$ with each other and the resource (Agrawal and Gibson 1999). Such institutions that affect $\mathrm{CF}$ are found the different level from local to central and global. Among the different types of institution, those related to property rights have long been recognized as an important pre-condition for effective management of the commons as they affects people's incentives, actions and, ultimately, economic and resource outcomes. Property right, as defined by Bromley (1992) is a claim to benefit streams with correlated duty attached to them. According to Bromley, rights are meaningless without correspondent duties. In addition to local level property right institution, those higher level institutions that shape the lower level one are also important. Different user groups, systems of property rights, types of commodities taken from a forest, and extant levels of rule enforcement interact with national legislation in different ways to produce particular patterns of forest use and conditions (Gibson et al. 2000). Furthermore, stability in the national and other level policy and other public instruments that provide property right on the forest for local people is vital. Local institutions would be willing to accept contracts with many land use and tree planting restrictions, provided that they have certainty that they and their families will be able to stay on the land for a relatively long period (Klooster and Masera 2000; Arifin et al. 2009).

\section{Methods}

\section{Study site description}

This study was conducted in two HKm farmer group areas, i.e. Bina Wana (BW) farmer group area and Jaya Lestari (JL) farmer group area (Fig. 1). Site A is located in the BW farmer group area, which is in Register 45b Bukit Rigis (8,295 ha), Tribudi Sukur and Tribudi Makmur villages, KebunTebu Sub-District, Lampung Barat District. Site B is located in the Jaya Lestari (JL) farmer group area, 
which is in protection-forest Register 24 Bukit Punggur (20,851 ha), Menangajaya Village, Banjit Sub-District, Way Kanan District. The two farmer groups were purposively selected for three reasons after preliminary discussions with Lampung Province Forestry officers. The first reason is that the two sites are representative of many other upland areas classified as "protection forest" in terms of their importance for local development (Verbist et al. 2005). Secondly, the two sites are among the sites that have experienced high deforestation particularly after the fall of the Suharto government during the 1999-2000 periods. Communities used the authority vacuum to cut forests and replaced them with agricultural crops such as coffee, cocoa, rubber, and palm oil (Miyamoto 2009). This demand for
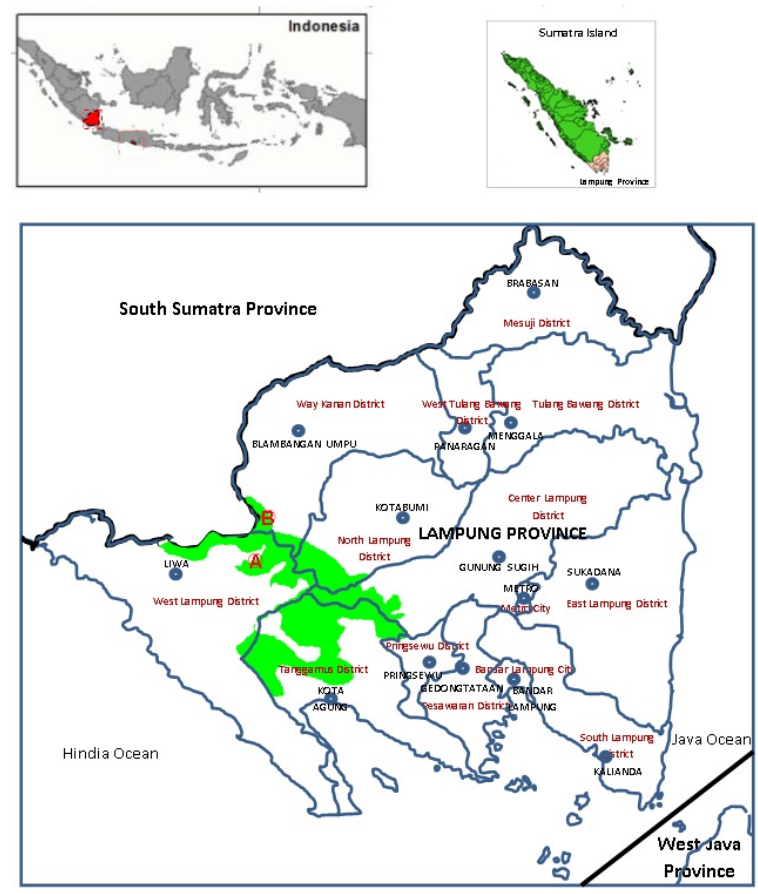

Fig. 1. Situation map of study site. Site A: BinaWana farmer group area. Site B: Jaya Lestari farmer group area. investigation of $\mathrm{HKm}$ approach that demands involvement of local communities to be effective interms of protection of the forest. Finally, both study sites are in the Way Besay catchment area, which is useful for hydroelectric power and as an irrigation water source for five lower-lying districts. Farmland plots used by BW and JL farmer groups in protection forests were registers 45b Bukit Rigis and 24 Bukit Punggur, respectively. Detailed description of the characteristics of HKm permit area is presented in Table 2 (Fig. 1, Table 2).

\section{Data collection and analysis}

Data was collected using open ended and semi-structured questionnaire interview, direct observation as well as document and archival reviews. Open ended interview was conducted in two ways, the first being with purposefully selected government staffs from Village, sub-district, district, province and national level. The discussion was conducted with individual officers at their office to collect data on the process of implementation of $\mathrm{HKm}$ and challenges faced. Open ended interview was also conducted during group discussion with members of $\mathrm{HKm}$ to investigate the process of HKM group rule making, planning, decision making, management methods etc. The group discussion was conducted with a total of five group comprised of a maximum of $8 \mathrm{HKm}$ members.

Socio economic data such as age, ethnicitys, formal and informal education, monthly income, cultivation area of farmer; data on tree planting, type and number of species planted etc; and data on farmers' reason for participation on $\mathrm{HKm}$, their perception of the role they have in the implementation process, the reason for participation in $\mathrm{HKm}$ and the significance of the program was collected using semi- structured questionnaire interview. A total of 108 respondent, which is $10 \%$ of members of each farmer group, were selected randomly (48 BW farmers and $60 \mathrm{JL}$ farm-

Table 2. HKm farmer groups permits areas

\begin{tabular}{llllllll}
\hline \multirow{2}{*}{$\begin{array}{c}\text { HKm } \\
\text { farmer group }\end{array}$} & District & Sub district & Village & Register & \multicolumn{3}{c}{ HKm area (ha) } \\
\cline { 5 - 9 } & & & & $\begin{array}{c}\text { Cultivation } \\
\text { block }\end{array}$ & $\begin{array}{c}\text { Protection } \\
\text { block }\end{array}$ & $\begin{array}{c}\text { Total area } \\
\text { (ha) }\end{array}$ \\
\hline Bina Wana & West Lampung & Kebun Tebu & Tribudi Syukur, Tribudi Makmur & 45 B Bukit Rigis & 470 & 175 & 645 \\
Jaya Lestari & Way Kanan & Banjit & Menanga jaya & 24 Bukit Punggur & $1,003.5$ & 291.5 & 1,295 \\
\hline
\end{tabular}


ers) for the semi-structured and structured questionnaire.

Documents including policy, decrees, regulations, master plans etc at national, regional, provincials and/or district level, management plans of $\mathrm{HKm}$ farmers as well as archival records were used to collect data on the de jure framework for HKm implementation, size of forest under HKm farmers and $\mathrm{HKm}$ memberships. Direct observation was used to triangulate the data on vegetation cover. The data was analyzed qualitatively and using descriptive statistics such as average and percentage.

\section{Results and Discussion}

In line with the three objectives of the study, the result and discussion are divided in to three. The first section elaborates the overall process of implementation of $\mathrm{HKm}$, followed by current status of $\mathrm{Hkm}$ farmers, their vegetation and their management activities. Finally the challenges faced by the program are presented.

\section{HKm implementation Process}

\section{Formation of $\mathrm{HKm}$ farmer groups}

$\mathrm{HKm}$ was established in 1995 after the central government issued Ministry of Forestry Decree no. 622/Kpts-II/ 1995 on protection and production forests. With an increase in the limited government resources for tackling deforestation, the government launched the HKm program. The program grants forest management permission to nearby communities whose livelihoods depend on forests to sustainably manage the forest. The 1998 financial crisis and collapse of the Suharto regime had an important impact on the overall implementation of HKm. Particularly, community participation was strengthened after 1998 (Arifin et al. 2009). The political changes also affected the CF program. In line with the overall political change, decree governing HKm program was superseded by Decree no. 677/Kpts-II/ 1998. The following major changes were made in the decree: in particular conservation forests is state forests but in particular zones, it can be managed via community participation through institutional cooperation under which proposals are made to the Ministry of Forestry to perform traditional forest management, to prepare a Master Plan, Five-Year Plan, and an Annual Plan, and to perform HKm management within 35 years. Decree no. 677/Kpts-II/1998 was superseded by Decree no. 31/Kpts-II/2001, which made the following modifications. The first one is $\mathrm{HKm}$ to be implemented only in protection and production forests. In addition, farmer groups are first granted temporary permits for the first three to five years. In the fourth year, the district government performs an evaluation. If evaluation results, measured in terms of the criteria set by the district government, is found to be acceptable, farmer groups will get permanent permits which are valid for 35 years. Since then $\mathrm{CF}$ in protection forest has been implemented.

$\mathrm{HKm}$ in Lampung Province was started in 1999 with a total area of 495.2 ha, based on the second HKm regulation. At that time $\mathrm{HKm}$ could set policies on protection and production, and define zones in conservation forests. Several HKm groups have formed in Lampung Province, including in a conservation forest, for which the outcome is still unclear. In 2011 the existing permit for $\mathrm{HKm}$ in Lampung Province was for 35,718.61 ha, which in Lampung Barat, North Lampung, Tanggamus, Central Lampung, and Way Kanan district. The HKm target for Renstra ("Strategic Plan") 2010-2014 in Lampung Province is 68,900 ha used by 75 farmer groups.

Specifically in the study area, the formation of farmer groups was as follows. BW was formed by the members themselves. Fortunately a Lampung Barat forestry officer lived in the BW farmers' village, enabling him to assist the BW farmer group. In 2000 BW Farmer Group obtained its first contract and began its forest management activities, including organizing a local group of rangers to monitor remaining forest areas and meeting regularly. The BW farmer group comprises 15 subgroups with a total of 478 farmers.

Based on Forestry Ministry Decree No. 31/Menhut-II/ 2001, BW HKm's contracts (permit number 439/Kwl-4/ Kpts/2000; 23 December 2000) are valid for an initial five-year probationary period, and can then be extended for another 25 years after evaluation. In 2005, the five-year $\mathrm{HKm}$ permit of BW group farmers was evaluated by a Lampung Barat District forestry officer. The BW farmer group passed the evaluation and received a 25 -year permit in 2006. After Forestry Ministry Decree No. P.37/ Menhut-II/2007 was issued by the Ministry of Forestry, the 25-year $\mathrm{HKm}$ permit for BinaWanaHKm farmer group was revoked and changed by Forestry Ministry 
Decree No. SK. 434/Menhut-II/2007 and by Lampung Barat District Decree No. B/1454/KPTS/III.05/2007 to manage 645 ha (470 ha cultivation block and 175 ha protection block) of register 45B Bukit Rigis for 35 years. During the overall implementation of $\mathrm{HKm}$ in BW, a local NGO (WATALA) provided institutional guidance them. In 2003-2009, an international NGO (ICRAF) also provided support related to $\mathrm{HKm}$ management and land research.

The JL farmer group was proposed in 2009 and granted a permit by Forestry Ministry Decree No. SK. 447/Menhut-II/2011 and by Way Kanan District Decree No. B 124/III.06-WK/2011 to manage 1,295 ha (1,003.5 ha cultivation block and 291.5 ha protection block) of register 24 Bukit Punggur. Most members of the JL group came from farmer groups who were active in the national forest rehabilitation program/GNRHL in 2003. The group was developed by officials of the Way Kanan District Forestry Office to be this HKm group. The JL farmer group comprises nine subgroups and 600 farmers, who are residents of Menangajaya Village, Banjit Sub-District, WayKanan District. In 2011, Wana Lestari Center Cooperative was established. It has five already-formed cooperative units and 12 units in the process of formation (to be completed by late 2012). One unit that has been formed is Jaya Lestari Cooperative Unit. Wana Lestari Center Cooperative was established and supported by the Way Kanan District government to promote the forest products of Way Kanan District's HKm farmers, especially rubber. The cooperative entered into a MoU or contract with PT Masdec Siger for the marketing of rubber. Further activities by the Way Kanan District Forestry Officers are data collection, taking photographs of farmers, land measurements, and making proposals.

\section{Forest management under $\mathrm{HKm}$ scheme}

$\mathrm{HKm}$ management plan is divided into a general plan and an operational plan. The general plan is the management plan for the HKm work area. It provides prescriptions for the preservation of the HKm area's economical, ecological, and social functions for one management period. The plan is prepared in a participatory manner and facilitated by the relevant authorities with training, guidance, and other assistance. The plan may be revised by the permit holder and authorized by the grantor. The operational plan is a more detailed elaboration of the general plan and includes many activities to be implemented over the following one-year period. The operational plan is also prepared in a participatory manner, facilitated by relevant agencies or other parties, and approved by the head of the District Forestry Service.

Community participation in $\mathrm{HKm}$ as per the aforementioned management plans involves utilization planning and implementation of forest management activities including boundary demarcation, planting, maintaining, protecting, harvesting, processing, marketing, paying fees in accordance with royalties for forest resources, and submitting yearly reports on the utilization of $\mathrm{HKm}$ areas to the district government head. In addition to these in situ managements, they also involved in protecting the forest from outsiders. Boundary demarcation involves marking $\mathrm{HKm}$ work areas, farmland plots, and dividing $\mathrm{HKm}$ areas according to their function. Participants may be individuals or groups, or people may participate through cooperatives. Each participant is entitled to manage up to 4 ha of forest. The management period is 35 years and must be evaluated every five years.

Planting, an important management activity by the farmers, involves woody plants and multi-purpose tree species (MPTs). The purpose of such planting is to enrich or expand existing farmland cover to create a multi-strata crown. In addition to planting, farmland maintenance and security are also performed by $\mathrm{HKm}$ farmer group members. These activities include sprouting buds, making terraces and root air vents, fertilizing, pest and disease prevention, and eliminating fire hazards. The Lampung Barat District Forestry Office requires the BW HKm farmer group to plant a minimum of 400 trees to be managed to give multi-strata canopy landscape on their farmland. Consequently, the BW farmer group planted as many as 12,000 rattan seedlings in their conservation area. The seedlings were supplied by the Lampung Barat District Forest Service. Way Kanan District Forestry Office, on the other hand, has no rules on the number of trees. Despite lack of such rules, the JL farmer group mentioned to have planted 400 trees in their $\mathrm{HKm}$ area. There are many non-coffee trees of various heights in their cultivation area, making up a multi-strata forest landscape. These are known as multi-strata coffee 
Table 3. Farmers'reasons for joining HKm scheme (percentage of respondents)

\begin{tabular}{lcccccc}
\hline \multirow{2}{*}{$\begin{array}{c}\text { HKm farmer } \\
\text { group }\end{array}$} & Peace & Income & Maintain forest & $\begin{array}{c}\text { Follow government } \\
\text { program }\end{array}$ & $\begin{array}{c}\text { Get certificate/ } \\
\text { permission }\end{array}$ & $\begin{array}{c}\text { Get assistance and } \\
\text { experience }\end{array}$ \\
\cline { 2 - 7 } & & $11(22.92)$ & $2(4.17)$ & $9(18.75)$ & $26(54.17)$ & $13(27.08)$ \\
Bina Wana & $12(25.00)$ & $7(11.67)$ & $3(5.00)$ & $20(33.33)$ & $13(27.08)$ & $12(20.00)$ \\
Jaya Lestari & $15(25.00)$ & $18(16.67)$ & $5(4.63)$ & $29(26.85)$ & $39(81.25)$ & $25(23.15)$ \\
Total & $27(25.00)$ & &
\end{tabular}

plantations which provide better soil and water conservation than coffee shade trees and monocultures (Buana et al. 2005).

The benefits for HKM participant for taking the responsibility to manage the forest is detailed in the Ijin Usaha Pengelolaan Hutan Kemasyarakatan (IUPHKm, meaning $\mathrm{HKm}$ license) in protection forests. According to this recent license, the benefits are is divided into area utilization, environmental services, and collection of NTFPs. Forest area use includes the cultivation of medicinal plants, ornamental plants, MPT species, and mushrooms, as well as beekeeping, collecting bird nests, captive breeding of wildlife, and gathering of livestock forage. Environmental services include the utilization of water services, nature tourism, biodiversity protection, preservation and protection of the environment, or carbon sequestration. NTFPs collected are rattan, bamboo, honey, sap, fruit, and mushrooms.

Payment of the forest resource royalty (Provisi Sumber Daya Hutan/PSDH) is an obligation of IUPHKm holders. The PSDH amount is determined by the Ministry Forestry. Because IUPHKm holders are expected to enjoy the above mentioned benefits of the forest, the government has obligated them to pay PSDH in order to regenerate the forests (Greenomics Indonesia and Indonesia Corruption Watch 2004). Finally, regarding report of utilization area, neither of the HKm farmer groups have filed an area utilization report. This is actually quite unusual because in 11 years there has been no reported use of HKm regions by farmer groups.

\section{Reason of farmer participation on $\mathrm{HKm}$ program}

The four major reasons for farmers' participation in $\mathrm{HKm}$ program were to get certificate/ permission, to follow government program, issues related to peace and to obtain assistance respectively (Table 3). Most farmers do so to obtain $\mathrm{HKm}$ permits and can manage forest land without concerns about being expelled by the government or other parties who want to use the land. By participating in the HKm program, farmers obtain secured right on the previously illegal farmland they used to cultivate inside the forest. The other reason, which is also related to property right security and safety is, to follow governments program and to have peaceful relation with other stakeholders. All respondents admitted that the land they till is government-owned protection forest. Therefore, they say they are obligated to follow the program. If farmers do not abide by the HKm program, their use of state forest land is considered illegal act, and they can be arrested for encroaching on government land. Possibility of getting assistance from NGOs and other actors as well as the training experience they obtain from involving in $\mathrm{HKm}$ was also the next important factors that motivated farmers to attend the program.

Another reason for participation is income. By farming in $\mathrm{HKm}$ areas, farmers can harvest NTFPs and determine the value of environmental services, which they sell to get income. Coffee planted in the BW farmer group area already has the value of Indonesian Rupiah (IDR) 12,500 per kg dried coffee. Rubber planted in the JL farmer group area yields latex worth IDR 10,500 per kg. Other harvested NTFPs are durians, bananas, and jackfruit, while forest environmental services have not been developed to use for water services, tourism, and carbon sequestration. This is due to the shortage of skilled farmers who are capable to manage and organize environmental services. If managed well, they can increase the incomes of $\mathrm{HKm}$ farmer groups.

The last reason is that farmers want to preserve forests which provide harvests that benefit them. Benefits are in the form of NTFPs and environmental services. They maintain their cultivation blocks by planting trees as in 
Table 4. Farmers' perceived role in HKm (in percentage of respondents)

\begin{tabular}{lcccccc}
\hline & \multicolumn{5}{c}{ Role } \\
\cline { 2 - 7 } $\begin{array}{c}\text { HKm farmer } \\
\text { group }\end{array}$ & $\begin{array}{c}\text { Growing and } \\
\text { conserving trees }\end{array}$ & Making terraces & $\begin{array}{c}\text { Attending } \\
\text { meetings }\end{array}$ & $\begin{array}{c}\text { Following farmer } \\
\text { group or } \\
\text { government rules }\end{array}$ & $\begin{array}{c}\text { Coming up with } \\
\text { ideas for HKm } \\
\text { groups }\end{array}$ & None \\
\hline Bina Wana & 67 & 56 & 19 & 73 & 17 & 6 \\
Jaya Lestari & 25 & 3 & 17 & 38 & 17 & 7 \\
Total & 44 & 27 & 18 & 54 & 17 & 6 \\
\hline
\end{tabular}

agroforestry to maintain forest functions. In addition, they defend protection blocks in $\mathrm{HKm}$ areas from forest encroachers and illegal loggers by keeping each cultivation block and protection block near their residences and cultivation areas, and by organizing forest protection groups (Table 3).

\section{Farmers' perceptions of their role in HKm program}

Following farmer group or government rules, growing and conserving trees, making terraces and attending meetings were the four major activities that the farmers perceived to be their role in $\mathrm{HKm}$ (Table 4). This is also in line with the above motivation to participate in the program. Since most of the farmers participate to follow government program and to have secured right on the land they cultivate, their perception of what they should do was also inline with fulfilling the government requirements. Consequently most farmers perceived their role to be following $\mathrm{HKm}$ government rules. The farmers' perception of their role to conserve and plant tree was also in line with following the government requirement. As discussed in the aforementioned section, the Lampung Barat District Decree demands farmer to plant and conserve trees while the Way Kanan District Forestry is yet to determine the number of tree to be planted.

The farmers also mentioned implementing group rules as their major role. HKm group rules were created by the farmers at group meetings, where each member has an equal right to state his or her opinion. Furthermore, the rules are set forth in the charter and bylaws of farmer groups. HKm group rules include member obligations and rights. Respondents stated that they had carried out obligations. Unlike the aforementioned activities, following the group rule was important because of their need to keep community cohesion as well as the process in which the rule of created, i.e. with participation of all members.

Building terraces is the other important role that the famers felt to be their responsibility. Terraces are a necessity because farmland is mountainous. The BW HKm farmer group has a higher awareness of conservation because of members' better knowledge about soil conservation, which they gained from an Indonesian NGO (WATALA) and an international NGO (ICRAF) through training and research. Conservationist practiced in various ways such as planting certain plants such as grasses or legumes, building conservation structures (ridges, terraces, and sediment pits), or a combination of both. Using both biological and mechanical conservation methods reduces soil erosion so as to maintain soil fertility. Respondents who did not make terraces claim that it is costly and time-consuming.

Farmers also attend meetings held by groups and subgroups, as their presence is needed at a variety of meetings related to $\mathrm{HKm}$ activities, including regular meetings held every three months by subgroups and annual meetings by groups. These regular meetings discuss technical issues concerning cultivation, new laws and regulations, institutional development, fees, and other matters associated with $\mathrm{HKm}$ management. Overall, only a small percentage of farmers think they have no role in particular. Farmers in this category are usually less active, and therefore know little about $\mathrm{HKm}$ activities (Table 4 ).

\section{Current status of HKm farmers and vegetation}

\section{Current socioeconomic situations of $\mathrm{HKm}$ farmers}

The socioeconomic situation of HKm farmers such as farmer age, ethnics, formal and informal education, monthly income as well as cultivation area of farmer is summarized in Table 5 . In terms of farmers' age, both HKm groups 
Table 5. Farmer groups characteristics

\begin{tabular}{|c|c|c|c|}
\hline \multirow{2}{*}{ Socioeconomic characteristics } & \multicolumn{3}{|c|}{ Proportion of farmers; (\%) } \\
\hline & Bina Wana & Jaya Lestari & Total \\
\hline \multicolumn{4}{|l|}{ Age } \\
\hline $25-50$ & $38(79.17)$ & $52(86.67)$ & $90(83.33)$ \\
\hline$>50$ & $10(20.83)$ & $8(13.33)$ & $18(16.67)$ \\
\hline \multicolumn{4}{|l|}{ Ethnic } \\
\hline Sundanese & $40(83.33)$ & $9(15.00)$ & $49(45.37)$ \\
\hline Javanese & $6(12.50)$ & $36(60.00)$ & $42(38.89)$ \\
\hline Lampung Sumendo & $2(4.17)$ & $15(25.00)$ & $17(15.74)$ \\
\hline \multicolumn{4}{|l|}{ Education } \\
\hline C Packet & $1(2.08)$ & $0(0.00)$ & $1(0.93)$ \\
\hline Elementary School & $21(43.75)$ & $30(50.00)$ & $51(47.22)$ \\
\hline Yunior high School & $12(25.00)$ & $21(35.00)$ & $33(30.56)$ \\
\hline High School & $14(29.17)$ & $9(15.00)$ & $23(21.30)$ \\
\hline \multicolumn{4}{|l|}{ Training } \\
\hline None & $11(22.92)$ & $28(46.67)$ & $39(36.11)$ \\
\hline Maximum 2 times & $24(50.00)$ & $28(46.67)$ & $52(48.15)$ \\
\hline More than 2 times & $13(27.08)$ & $4(6.67)$ & $17(15.74)$ \\
\hline \multicolumn{4}{|l|}{ Monthly income } \\
\hline \multicolumn{4}{|l|}{ Maximum 1 million IDR } \\
\hline $\mathrm{HKm}$ & $35(72.92)$ & $36(60.00)$ & $71(65.74)$ \\
\hline Non-HKm & $25(52.08)$ & $45(75.00)$ & $70(64.81)$ \\
\hline \multicolumn{4}{|l|}{ More than 1-2 million IDR } \\
\hline $\mathrm{HKm}$ & $10(20.83)$ & $18(30.00)$ & $28(25.93)$ \\
\hline Non-HKm & $13(27.08)$ & $10(16.67)$ & $23(21.30)$ \\
\hline \multicolumn{4}{|l|}{ More than 2 million IDR } \\
\hline $\mathrm{HKm}$ & $3(6.25)$ & $6(10.00)$ & $9(8.33)$ \\
\hline Non-HKm & $10(20.83)$ & $5(8.33)$ & $15(13.89)$ \\
\hline \multicolumn{4}{|l|}{ Cultivation area of farmer } \\
\hline Maximum 1 ha & $40(83.33)$ & $14(23.33)$ & $54(50.00)$ \\
\hline More than 1-2 ha & $8(16.67)$ & $27(45.00)$ & $35(32.41)$ \\
\hline More than 2 ha & $0(0.00)$ & $9(15.00)$ & $9(8.33)$ \\
\hline Non-HKm Area & $39(81.25)$ & $18(30.00)$ & $57(52.78)$ \\
\hline HKM/ Non-HKm & 1.23 & 3.33 & 2.3 \\
\hline \multicolumn{4}{|l|}{ Origin of farmers } \\
\hline Outside of Lampung Province & $10(20.83)$ & $22(36.67)$ & $32(29.63)$ \\
\hline Outside of district & $19(39.58)$ & $24(40.00)$ & $43(39.81)$ \\
\hline Born in district & $19(39.58)$ & $14(23.33)$ & $33(30.56)$ \\
\hline \multicolumn{4}{|l|}{ Origin of cultivated land } \\
\hline Inherited from parents & $19(39.58)$ & $18(30.00)$ & $37(34.26)$ \\
\hline Cleared forest & $12(25.00)$ & $12(20.00)$ & $23(21.30)$ \\
\hline Purchased & $17(35.42)$ & $28(46.67)$ & $45(41.67)$ \\
\hline Renting & $0(0)$ & $2(3.33)$ & $2(1.85)$ \\
\hline From government & $0(0)$ & $0(0)$ & $1(0.93)$ \\
\hline \multicolumn{4}{|l|}{ Have cultivated land since } \\
\hline Before 2000 & $25(52.08)$ & $29(48.33)$ & $54(50.00)$ \\
\hline $2000-2007$ & $22(45.83)$ & $21(35.00)$ & $43(39.81)$ \\
\hline After 2007 & $1(2.08)$ & $10(16.67)$ & $11(10.19)$ \\
\hline
\end{tabular}

$\$ 1 \approx$ IDR 9,727. 
have farmers that are in their prime. This is very beneficial for the HKm program, because farmers can easily perform most $\mathrm{HKm}$ activities. BW farmer group is dominated by Sundanese, while JL is dominated by Javanese. Farmers migrated into these areas as plantation labor.

Most farmers in both groups attended middle school and high school (Table 5). In addition, most farmers in both groups also attended training at least twice. Training is carried out by the local NGO WATALA, which provides training in many skills such as drawing up plans, leadership, writing annual reports, coffee cultivation, terracing, and fertilizing. Training is also provided by ICRAF, such as terracing, agroforestry, and calculating the monetary value of nature's environmental services. Lampung Barat Forest Service trains BW farmers in skills such as forest planting and management. JL HKm farmer group received training from the Way Kanan District Forest Service, such as in rubber cultivation, honey bee management, and rubber tapping. In addition, PT Masdeg also conducted training in rubber tapping. With such training, farmers were expected to increase crop production while maintaining the ecological functions of forests. Training also makes farmers better understand their problems and participate more fully in the HKm program in the hope of finding solutions to their problem.

In terms of monthly income, for lowest income, percentage of BW farmers who have income from HKm more than $\mathrm{JL}$ farmers and vice versa on income from non HKm. For middle and highest income, percentage of BW farmers who have income from HKm less than JL farmers and vice versa on income from non $\mathrm{HKm}$. The monthly income of farmers in both $\mathrm{HKm}$ groups who have low incomes also have a high dependence on the forest. Farmers who earn more than IDR 1 million have lower forest dependence in BW group than in JL group. High income is also associated with more private land ownership in BW than in JL. Accordingly, farmers in BW have lower forest dependence than those in JL (Table 5).

BW HKm farmer group has less farmland than JL $\mathrm{HKm}$ farmer group. Nevertheless BW HKm farmer group has land outside the $\mathrm{HKm}$ area because the farmers have been able to buy land outside the area. In this sense, $\mathrm{JL}$ farmers depend more on the forest than BW farmers do. Some farmers cannot cultivate their HKm areas by them- selves, so they share their land with other farmers. The harvests are shared.

Most farmer groups in Lampung Province acquired half their farmland before 2000, and almost half of the rest by purchase (Table 5). The BW farmer group inherited farmland and bought almost the same amount, while the JL group purchased nearly half its farmland. Only about $20 \%$ of farmers cleared land for cultivation. Respondent farmers and forestry officials claimed that although land was cleared in the past, clearing is no longer done owing to the close supervision of farmer groups and the government. At present, anyone caught clearing land would suffer consequences (Table 5).

\section{Current vegetation conditions of $\mathrm{HKm}$ area}

Land tended by BW farmers is less dense than that tended by JL farmers, but it has more woody trees and multi-purpose trees species (MPTs) per unit area (Table 6). BW farmers have more coffee trees on their land because they still retain coffee as their main crop. Based on the results of interviews with respondents, they keep many coffee trees because, despite varying coffee prices, there is a promising market and they are already skilled in managing

Table 6. Number of species and stem of trees in HKm area

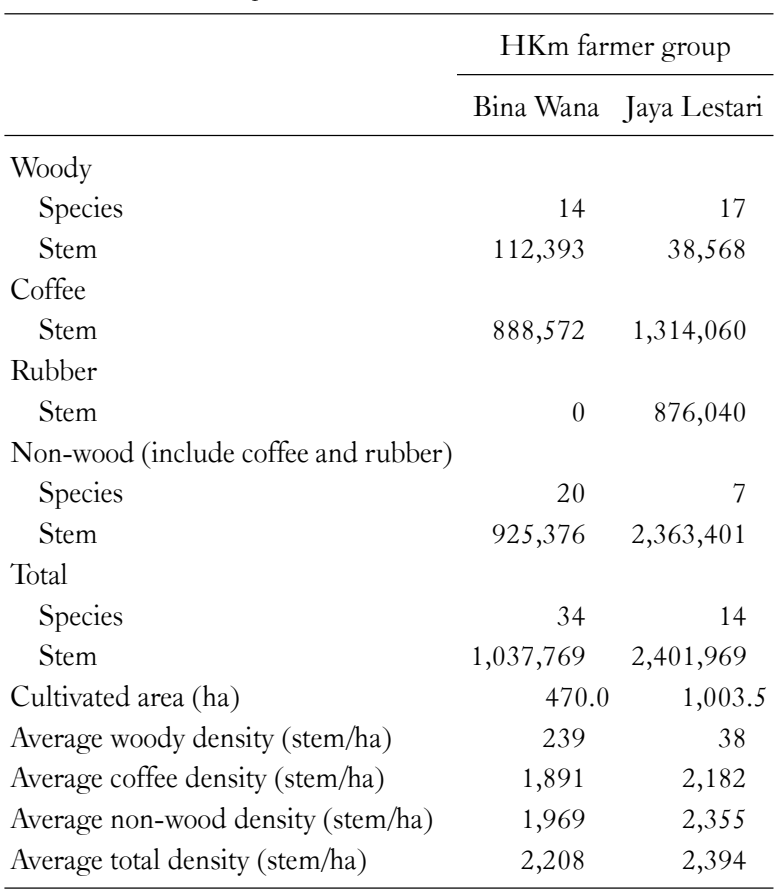


coffee. This predilection for coffee in particular is likely to be a problem for timber tree management unless farmers are allowed to periodically harvest timber trees, or unless tree planting and protection requirements are strictly enforced (Pender et al. 2008) (Table 6).

In 2003 the central government instituted the GNRHL program on 400 ha of BW farmland at the BW site. Those 400 ha account for the entire farmland in subgroups 2 through 11 and most land in subgroup 1. Generally crops under the GNRHL program are woody plants and MPTs planted at a 70:30 ratio and the amount of timber trees increased especially in the BW area (Pender et al. 2008). Regarding MPTs plants, BW farmer group respondents were not concerned because NTFPs can be harvested and used by $\mathrm{HKm}$ farmers, but all respondents objected to planting woody plants because they cannot use the timber under the rule which bans logging in protection forests, and their coffee trees would produce less or even die.

BW farmer group members perform maintenance for their main crop (coffee). Farmers maintain enrichment plants by pruning them and guarding against fire. It is generally believed that enrichment plants grow well owing to the care given to coffee plants. Some enrichment plants are the GNRHL program's woody plants and MPTs. Security activities are also carried out by farmer group members on their own farmland. Maintenance is not done in conservation areas because they are still forests whose natural processes make the forests self-maintaining. Security activities in conservation areas are performed by a forest protection cadre (PAM hutan) consisting of eight people and assisted by the subgroups' management boards. It is also assisted by farmer group members who have farmland adjacent to conservation areas. PAM hutan cadre members patrol conservation areas once a month in shifts.

Most JL farmers (75\%) had replaced their coffee plants with rubber trees, and almost all $(83.33 \%)$ had planted rubber trees (Table 7). Rubber trees are MPT plants, which were include in NTFPs in accordance with the regulations of Ministry of Forestry P.35/Menhut-II/2007 on NTFPs, while coffee is a plantation crop. Additionally, rubber plants have advantages such as: they are easy to maintain, latex can be harvested five times a week, they have a longer productive period than coffee, there is a good market in Way Kanan District, and can get prices up to IDR $10,500 / \mathrm{kg}$ for latex. However, based on information from farmers, the production of rubber trees decreases at altitudes above 600 m. JL farmers have built Wana Lestari, a cooperative that aims to unite the $\mathrm{HKm}$ farmers in register 24 Bukit Punggur so as to have high bargaining power when negotiating or contracting with the buyer company. A contract was concluded between Wana Lestari Center Cooperative and PT Masdeg for the processing of rubber. The contract stated that the company will buy latex of rubber at a price above that paid by middlemen. This is of course very helpful in improving farmer welfare. With higher rubber prices, farmers will more actively participate in the HKm program because of the economic benefit (Hlaing and Inoue 2013). Some crops on JL farmer group's land, including rubber trees, are from the 2003 GNRHL program. This program was conducted on 400 ha of the JL farmer group's farmland, which included all of subgroups 1, 7, and 8, as well as most of subgroups 2,3 , and 5 .

$\mathrm{JL}$ farmer group maintenance on major crops such as rubber involves pruning, fertilizing, controlling pests and diseases, and eliminating fire hazards. Most major crops are GNRHL's plants, provided in 2003. Each group mem-

Table 7. Farmers who have commodities in HKm area (percentage of respondents)

\begin{tabular}{lcc}
\hline \multirow{2}{*}{ Commodity } & \multicolumn{2}{c}{ HKm farmer group } \\
\cline { 2 - 3 } Coffee & Bina Wana & Jaya Lestari \\
Rubber & $48(100)$ & $55(91.67)$ \\
Banana & 0 & $50(83.33)$ \\
King fruits & $11(22.92)$ & $1(1.67)$ \\
Mango & $6(12.5)$ & 0 \\
Jack fruits & $1(2.08)$ & 0 \\
Avocado & $1(2.08)$ & 0 \\
Dogfruit & 0 & $2(3.33)$ \\
Cocoa & 0 & $6(10)$ \\
Pepper & $17(35.42)$ & $4(6.67)$ \\
Sugar palm & $22(48.83)$ & $2(3.33)$ \\
Candleberry & $3(6.25)$ & $1(1.67)$ \\
Paddy & $6(12.5)$ & 0 \\
Cardamom & $6(12.5)$ & $2(3.33)$ \\
Fish & $1(2.08)$ & 0 \\
Tobacco & $1(2.08)$ & 0 \\
Clove & 0 & $1(1.67)$ \\
Cassava & 0 & $1(1.67)$ \\
\hline
\end{tabular}


Table 8. Treats to HKm implementation

\begin{tabular}{|c|c|c|c|}
\hline \multirow{2}{*}{ Treat } & \multicolumn{3}{|c|}{ Remark } \\
\hline & Confusion with respect to: & BW & $\mathrm{JL}$ \\
\hline \multicolumn{4}{|l|}{ Repeated change of regulation } \\
\hline $\begin{array}{l}\text { 677/Kpts-II/1998; 865/Kpts-II/1999; } \\
\text { 31/Kpts-II/2001 }\end{array}$ & HKm program begins & 1999 & 2007 \\
\hline P.37/Menhut-II/2007; P.18/Menhut-II/2009 & Limitation of $\mathrm{HKm}$ area of each farmer & No & Yes \\
\hline P.13/Menhut-II/2010; P.52/Menhut-II/2011 & Forest resource royalti $(\mathrm{PSDH})$ & Not yet & Already \\
\hline Low capacity & HKm farmer organization & HKm farmer group & $\begin{array}{l}\text { HKm farmer group } \\
\text { and cooperative }\end{array}$ \\
\hline No of HKM section Staff & & 4 & 2 \\
\hline Average Yearly Budget & & $\approx$ IDR 100 million & $\approx$ IDR 32.5 million \\
\hline
\end{tabular}

ber helps maintain security in the conservation area, especially the security of farmland adjacent to the conservation area. The JL farmer group does not have a PAM hutan cadre (Table 7).

\section{Treats for the implementation of $\mathrm{HKm}$}

\section{Frequent changes in $\mathrm{HKm}$ regulations and lack of ca-} pacity to implement it

Since its inauguration in 1995, the regulations for $\mathrm{HKm}$ have changed for about seven times (Table 8). This instability in the institution has created confusion and different interpretation of the regulation in the field. Such confusion were in relation to the commencement of the program, limitation of $\mathrm{HKm}$ area of each farmer, forest resource royalti $(\mathrm{PSDH})$ as well as type of organization involved in HKm (Table 8).

In addition to the repeated change in regulation, lack of capacity by the district office was also another problem for the implementation of the HKm. For example, during the research time, there were only a total of six staff members for a total of $63 \mathrm{Hkm}$ farmer groups that are under different stage of formation. These farmer groups are intended to manage about 71,000 ha area of forest land. Considering this size of the forest and the number of farmer groups, the number staff members were very small. In addition, the annual budget allocated for the office in the two study site, which is about IDR132,500,000 is quite small (Table 8).

\section{Difficulties faced by farmers to implement $\mathrm{HKm}$}

The first important difficulty faced by farmers is related to knowledge of implementing the aforementioned $\mathrm{HKm}$ program. They need guidance in HKm management such understanding the rules, applying for $\mathrm{HKm}$ permits, demarcation of land, cultivation, processing, marketing etc. In $\mathrm{BW}$, assistance from NGO seemed to play key role in minimizing this problem. BW HKm farmers created a measurement team themselves after receiving boundary-measurement training from WATALA. JL farmers hire a consultant team for measurement. Measurements performed by farmers themselves are low-cost because each farmer subgroup sends its representatives and does not have to pay measurement costs, but the disadvantage is that measurements take a long time. Measurements performed by a consultant team require less time but greater cost. Based on respondent information, each member paid measurement fees amounting to IDR 2.5 million per ha.

The BW farmer group also made a general/master plan in 2011 while in 2010 it developed its first operational plan, which was facilitated by WATALA. JL farmers have yet to draw up their general and operational plans. The JL farmer group chief said in an interview that the general and operational plans will be made this year after they finished measuring parcel boundaries of JL farmer group members. However, considering their limited understanding of development $\mathrm{f}$ master plan, this is going to be a problem.

Another problem faced by farmers is lack of seedlings. Because of shortage of seedlings, the JL group has not yet planted in their protected areas. Seedling aid or nursery production is necessary so that farmers can produce their own seeds and learn how to do it well. According to inter- 
views with officials, the JL farmer group wants a nursery and is seeking funding to create one. The nursery is intended for subgroups of $\mathrm{HKm}$ farmers because there are too few trees per ha in the area. Enrichment planting should be combined with the planting of seedlings from the nursery.

Finally, the last problem is related to lack of guideline. All respondents said in interviews that they were willing to calculate and pay their PSDH, which is usually done at harvest time, but on the condition that the basic rules are explained first. Difficulties were encountered with the BW farmer group's coffee crop because coffee and other NTFPs have no guidelines for PSDH calculation, and because coffee is not included among forestry commodities. The JL farmer group has no problem because PSDH can be calculated for their latex. The central government is still formulating $\mathrm{PSDH}$ rules for $\mathrm{HKm}$ areas through the Ministry of Forestry. In addition, HKm farmers have not benefited from the knowledge and understanding of PSDH.

\section{Conclusion and Policy Implication}

This paper explored the present condition of $\mathrm{HKm}$ program in Indonesia. The papers elaborated the process of formation of $\mathrm{HKm}$ implementation by exploring the process of farmers' formation, forest managements under $\mathrm{HKm}$, farmers' motivation for participation in HKm programs and farmers perception of their role in HKm farmers group. It also assessed the current socioeconomic conditions of the farmers and the vegetation they are managing. Finally it elaborated the two treats for effective implementation of the program, i.e. frequent change in regulation and farmers' lack of capacity to implement it.

In order to improve the ongoing implementation of $\mathrm{HKm}$, community empowerment of both individuals and institutions must be developed so that people have the awareness and ability to manage forests sustainably. Guidance by NGOs, universities, governments, and other stakeholders is necessary to enable forest farmers to implement the HKm program well. Technical guidance that could be provided to solve problems would be help in determining boundaries, drawing up general and annual plans, nurseries, preparing reports, maintenance and se- curity, and calculating PSDH. If farmers can calculate the PSDH correctly, they will not suffer losses and be periodically rewarded with harvests from the forest. In addition to technical guidance, material and financial assistance such as measuring equipment for mapping land, soft loans, seeds, and processing equipment will also improve the current implementation of $\mathrm{HKm}$.

It will be necessary to study ministerial regulations such as those for HKm (P.52/Menhut-II/2011), NTFP (P.35/ Menhut-II/2007), and PSDH (P.18/Menhut-II/2007). This is because the management of protection forests requires more energy than managing production forests, especially in relation to the functions of protection forest so that NTFPs can be harvested. Nevertheless, BW farmers still grow coffee which not includes NTFP in their HKm area. Therefore in relation to PSDH, further studies should be done on commodities, the PSDH amount that $\mathrm{HKm}$ farmers can receive, and how that benefits the management of protection forests.

In addition, the functions of protection forests are important for water and soil fertility, which makes the ecological aspect as important as the economic and social aspects. The number of woody plants and trees planted by forest farmers is an important factor in maintaining the ecological functions of $\mathrm{HKm}$ areas in protection forests. This needs to be coupled with the assessment and sale of environmental services such as water and carbon sequestration. Regulations related to carbon -Minister of Forestry P.30/Menhut-II/2009, P.36/Menhut-II/2009, and P.20/ Menhut-II/2012 should be implemented so that people can derive additional economic benefit from managing $\mathrm{HKm}$ forests.

\section{Acknowledgements}

We gratefully acknowledge the financial support for the field survey given by the Environment Research and Technology Development Fund (D-1005, headed by Professor Toshinori Okuda, Hiroshima University) of the Ministry of the Environment, Japan. We also grateful to Eny Puspa, Sarwo Edy Saputro, Helmie Salsabila, Rio Yudischa, Taufik Setiawan Messi, and Rio Sixth Nababan for their support in collecting data. 


\section{References}

Agrawal A, Gibson CC. 1999. Enchantment and disenchantment: the role of community in natural resource conservation. World Development 27: 629-649.

Akiefnawati R, Villamor GB, Zulfikar F, Budisetiawan I, Mulyoutami E, Ayat A, van Noordwijk M. 2010. Stewardship Agreement to Reduce Emissions from Deforestation and Degradation (REDD): Case study from Lubuk Beringin's Hutan Desa, Jambi Province, Sumatra, Indonesia. International Forestry Review 12: 349-360.

Arifin B, Swallow BM, Suyanto S, Coe RD. 2009. A conjoint analysis of farmer preference for community forestry contract in the Sumberjaya Watershed, Indonesia. Ecological Economics 68: 2040-2050.

Arifin B. 2006. Transaction cost analysis of upstream-downstream relations in watershed services: lessons from community-based forestry management in Sumatra, Indonesia. Quarterly Journal of International Agriculture 45: 361-376.

Balooni K, Inoue M. 2007. Decentralized forest management in South and Southeast Asia. Journal of Forestry 105: 414.

Bromley DW, Feeny D, McKean M, Peters P, Gilles J, Oakerson R, Runge CF, Thomson J. (eds) Making The Commons Work: Theory and Practice and Policy. Institute for Contemporary Studies. San Francisco.

Buana RY, Suyanto S, Hairiah K. 2005. Kebun Lindung: Kajian Ekologi dan Sosio-Ekonomi di Lampung Barat. Agrivita 27: 170-181. (in Indonesian with English abstract)

Colchester M. 2001. Bridging the Gap: Challenges to community forestry networking in Indonesia. CIFOR, Indonesia. http:// www.cifor.org/publications/pdf_files/CF/Indonesia_CF.pdf Accessed 7 Jul 2010.

Lampung Provincial Forestry Office. 2008. Buku Data dan Informasi Kehutanan Provinsi Lampung, 2008. Bandar Lampung. (in Indonesian).

Fay C, de Foresta H. 1998. Progress Towards Increasing the Role Local Play in Forest Lands Management in Indonesia. Southeast Asia Policy Research Working Paper, No. 27. International Center for Research in Agroforestry (ICRAF) Southeast Asia, Bogor, Indonesia.

Feeny D, Berkes F, Mccay BJ, Acheson JM. 1990. The tragedy of the commons: twenty-two years later. Hum Ecol 18: 1-19.

Gibson C, MacKean MA, Ostrom E. 2000. Explaining deforestation: The role of local institutions. In: People and Forests: Communities, Institutions, and Governance (Gibson C, MacKean MA, Ostrom E, eds). The MIT press, London, pp $1-26$.

Greenomics Indonesia, Indonesia Corruption Watch. 2004. Pungutan Usaha Kayu. Evolusi terhadap mekanisme perhitungan, pemungutan, dan penggunaan pungutan usaha kayu. Kertas Kerja. http://www.greenomics.org/docs/wp07.pdf Accessed 17 Apr 2012. (in Indonesian).
Hlaing EES, Inoue M. 2013. Factor affecting participation of user group members: comparative studies on two types of community forestry in the Dry Zone, Myanmar. J For Res 18: 60-72.

Klooster D, Masera O. 2000. Community forest management in Mexico: carbon mitigation and biodiversity conservation through rural development. Global Enviromental Change 10: 259-272.

Kubo H. 2008. Diffusion of Policy Discourse into Rural Spheres Through Co-Management of State Forestlands: Two Cases from West Java, Indonesia. Environmental Management 42: 80-92.

Kubo H, Supriyanto B. 2010. From fence-and-fine to participatory conservation: mechanisms of transformation in conservation governance at the gunung Halimun-Salak National Park, Indonesia. Biodiversity and Conservation 19: 1785-1803.

Larson AM, Soto F. 2008. Decentralization of natural resource governance regimes. Annual Review of Environment and Resources 33: 213-239.

Maryudi A, Devkota RR, Schusser C, Yufanyi C, Salla M, Aurenhammer H, Rotchanaphatharawit R, Krott M. 2012. Back to basics: Considerations in evaluating the outcomes of community forestry. Forest Policy and Economics 14: 1-5.

Miyamoto M. 2006. Forest conversion to rubber around sumatran villages in Indonesia: comparing the impacts of road construction, transmigration projects and population. Forest Policy and Economics 9: 1-12.

Mohammed AJ, Inoue M. 2012. Explaining disparity in outcome from community-based natural resource management (CBNRM): a case study in Chilimo Forest, Ethiopia. Journal of Environmental Planning and Management 55: 1248-1267.

Mohammed AJ, Inoue M. 2013. Exploring decentralized forest management in Ethiopia using actor-power-accountability framework: case study in West Shoa zone. Environment, Development and Sustainability 15: 807-825.

Martinus N, Makoto I. 2000. Local Forest Management in Indonesia: A Contradiction Between National Forest Policy and Reality. International Review for Environmental Strategies 1: 175-191.

Obidzinski K, Dermawan A. 2010. Smallholder timber plantation development in Indonesia: what is preventing progress? International Forestry Review 12: 339-348.

Ostrom E. 1990. Governing the commons: the evolution of institutions for collective action. Cambridge University Press, New York.

Ostrom E. 2007. Sustainable Social-Ecological System: impossibility? Conference paper presented in meetings of the American Association for the Advancement of Science, Science and Technology for Sustainable Well-Being, San Francisco., USA.

Pender J, Suyanto S, Kerr J, Kato E. 2008. Impacts of the Hutan Kemasyarakatan Social Forestry Program in the Sumberjaya Watershed, Lampung Barat District of Sumatra, Indonesia. IFPRI Discussion Paper No. 00769. 
Pulhin JM, Inoue M. 2008. Dynamics of devolution process in the management of the Philippine forests. International Journal of Social Forestry (IJSF) 1: 1-26.

Verbist B, Dinata AE, Budidarsono S. 2005. Factors Driving Land
Use Change: Effects on Watershed Functions in a Coffee Agroforestry System in Lampung, Sumatra. Agricultural Systems 85: 254-270. 